\title{
Oxidation of Spent Fuel During Fuel Handling Accidents Test Plan
}

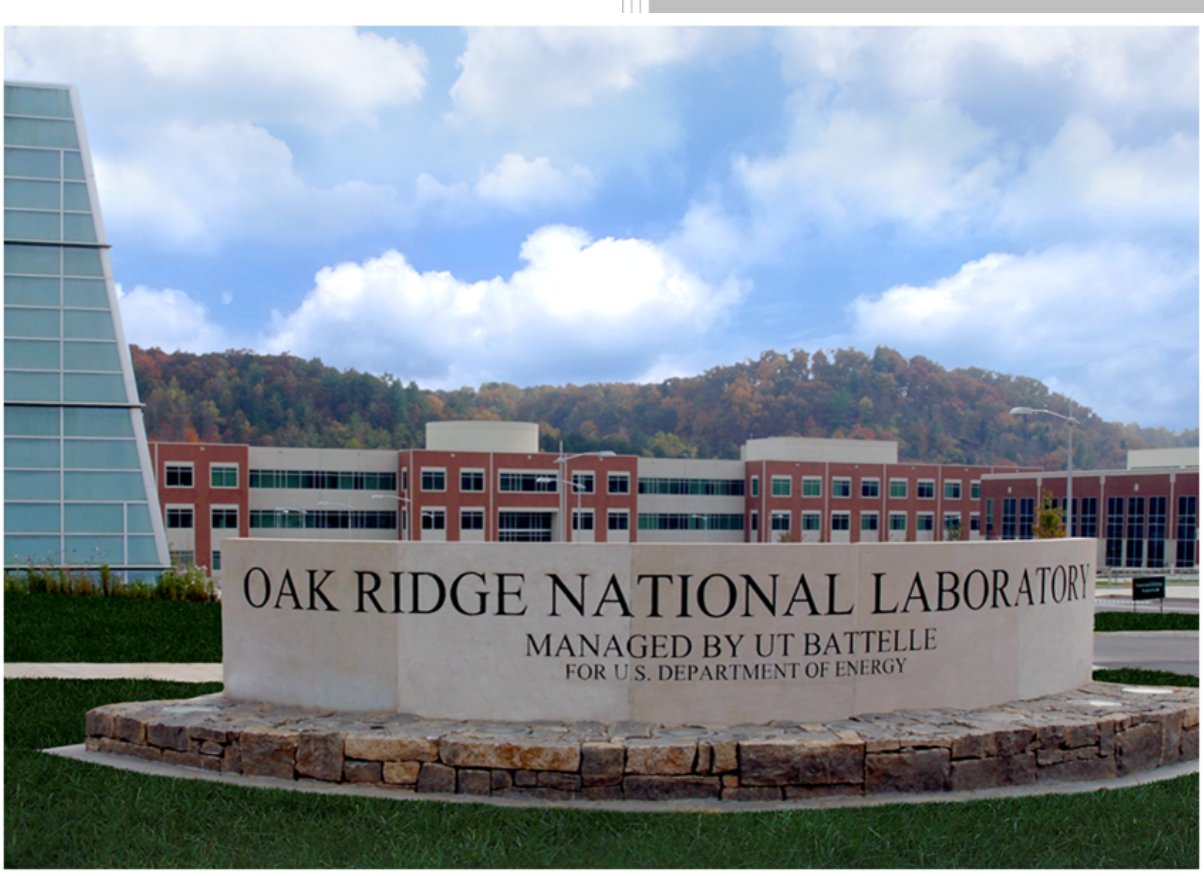

\section{Approved for public release.} Distribution is unlimited.

Jason M. Harp

Andrew T. Nelson

September 2019 


\section{DOCUMENT AVAILABILITY}

Reports produced after January 1, 1996, are generally available free via US Department of Energy (DOE) SciTech Connect.

Website www.osti.gov

Reports produced before January 1, 1996, may be purchased by members of the public from the following source:

National Technical Information Service

5285 Port Royal Road

Springfield, VA 22161

Telephone 703-605-6000 (1-800-553-6847)

TDD 703-487-4639

Fax 703-605-6900

E-mail info@ntis.gov

Website http://classic.ntis.gov/

Reports are available to DOE employees, DOE contractors, Energy Technology Data Exchange representatives, and International Nuclear Information System representatives from the following source:

Office of Scientific and Technical Information

PO Box 62

Oak Ridge, TN 37831

Telephone 865-576-8401

Fax 865-576-5728

E-mail reports@osti.gov

Website http://www.osti.gov/contact.html

This report was prepared as an account of work sponsored by an agency of the United States Government. Neither the United States Government nor any agency thereof, nor any of their employees, makes any warranty, express or implied, or assumes any legal liability or responsibility for the accuracy, completeness, or usefulness of any information, apparatus, product, or process disclosed, or represents that its use would not infringe privately owned rights. Reference herein to any specific commercial product, process, or service by trade name, trademark, manufacturer, or otherwise, does not necessarily constitute or imply its endorsement, recommendation, or favoring by the United States Government or any agency thereof. The views and opinions of authors expressed herein do not necessarily state or reflect those of the United States Government or any agency thereof. 
Reactor \& Nuclear Systems Division

\title{
Oxidation of Spent Fuel During Fuel Handling Accidents Test Plan
}

\author{
Author(s) \\ Jason M. Harp \\ Andrew T. Nelson
}

Date Published:

September 2019

Prepared by

OAK RIDGE NATIONAL LABORATORY

Oak Ridge, TN 37831-6283

managed by

UT-BATTELLE, LLC

for the

US DEPARTMENT OF ENERGY

under contract DE-AC05-00OR22725 


\section{CONTENTS}

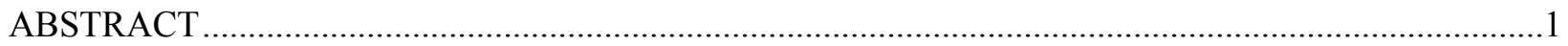

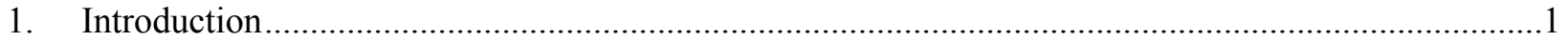

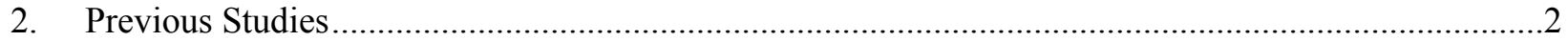

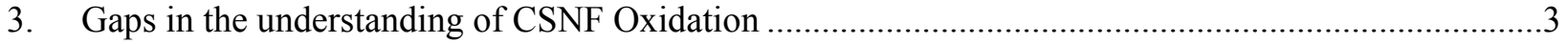

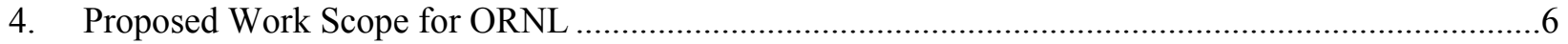

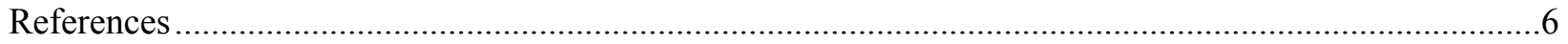




\section{INTRODUCTION}

The transfer of commercial spent nuclear fuel (CSNF) from transport or dry storage cask into final repository cask represents a scenario where fuel elements are potentially at risk to exposure to air and elevated temperatures. In the event of an accident during handling operations, the facility cooling may cease to function, and the temperature of the fuel would begin to rise due to decay heat generation. CSNF is generally stored in an inert environment, but handling operations could be performed in an air environment. If any damaged fuel elements are present during this postulated accident the fuel could begin to oxidize from $\mathrm{UO}_{2}$ to $\mathrm{U}_{3} \mathrm{O}_{8}$. If the oxidation event is severe, volume expansion from oxidation could result in large-scale cladding failure and large releases of CSNF debris into the transfer facility. Depending on the design of the fuel handling facility, any SNF release could have an impact on off-site dose.

To build a facility that can reasonably process the inventory of CSNF that is ready for a repository at a reasonable cost, handling in air may be necessary. To evaluate accidents at this facility the oxidation behavior of damaged CSNF needs to be well understood and characterized. It may also be necessary to understand the behavior of intact cladding in a fuel handling accident as well. Fortunately, some relevant information already exists since the oxidation of CSNF has been previously studied [1-4].

The progression of $\mathrm{UO}_{2}$ oxidation is well known. When exposed to an oxidizing atmosphere at elevated temperatures, $\mathrm{UO}_{2}$ will begin to oxidize along its grain boundaries to $\mathrm{U}_{4} \mathrm{O}_{9}$ which is denser than $\mathrm{UO}_{2}$. This densification of the fuel continues to expose fresh $\mathrm{UO}_{2}$ surfaces and pulverizes the $\mathrm{UO}_{2}$. As the reaction continues, $\mathrm{U}_{4} \mathrm{O}_{9}$ oxidizes further to $\mathrm{U}_{3} \mathrm{O}_{7}$ (at some temperatures and this step may not occur in irradiated fuel) then it oxidizes to $\mathrm{U}_{3} \mathrm{O}_{8}$, which is less dense than $\mathrm{UO}_{2}$. The $\mathrm{U}_{3} \mathrm{O}_{8}$ phase volume expansion can become particularly problematic in a spent fuel handling accident, and will begin to stress the cladding, potentially causing further cladding failure by widening the original gap in cladding that initially allowed air ingress and the fuel to begin oxidizing. Because the fuel is pulverized during oxidation, the expanded cladding breach can begin releasing a fine particulate of spent nuclear fuel (SNF) which could lead to off-site dose and will certainly require a significant decontamination effort in the CSNF handling facility. The oxidation of fuel and subsequent increased cladding failure also leads to the loss of containment of fission gases and other volatile fission products in the SNF, particularly Cs.

There are still some gaps that exist in the understanding of CSNF behavior. Specifically the following phenomena warrant further study to determine how they affect $\mathrm{UO}_{2}$ oxidation kinetics:

- The effect of final $\mathrm{UO}_{2}$ grain size

- The effect of final fuel chemistry (burnup)

- The effect of the High Burnup Structure or high burnup rim structure that can form under certain conditions

- Commercial reactor type: pressurized water reactor (PWR) vs. boiling water reactor (BWR), which changes cladding behavior (zircaloy-4 based cladding vs. zircaloy-2 based cladding), pellet size where BWR pellets are larger than PWR pellets and other differences.

The progression of fuel failure is also dependent on the properties of the cladding after irradiation and possible long term wet/dry storage. Other factors that impact SNF behavior in air include:

- High-temperature zirconium alloy creep

- Zirconium alloy fracture toughness as it relates to crack propagation

Another factor to consider is the size and shape of the initial defect in the fuel. The progression of oxidation is also impacted by the amount of moisture in the air. 
This report reviews the existing literature on CSNF oxidation and identifies gaps in the current knowledge of the oxidation of CNSF during a fuel handling accident. A proposed test plan to begin closing the knowledge gaps in CNSF oxidation follows the gap analysis.

\section{PREVIOUS STUDIES}

The consequences of a fuel handling accident resulting in the oxidation of damaged fuel have been studied when determining plans for permanent CSNF geologic repositories. Einziger and Strain summarize much of the work performed in the 1980s in their report and in a paper on the oxidation of PWR fuel $[1,2]$. From the mid-1980s, the basic problem was clear. If $\mathrm{UO}_{2}$ is exposed to air at elevated temperatures, it oxidizes, pulverizes, expands, and then produces a stress on the cladding that can continue down the length of cladding, resulting in a massive release of irradiated fuel. With the available data, Einziger and Strain established conservative time and temperature limits for in-air handling of fuel with pre-existing defects. Data needs were also identified that specified the need to understand some specific radionuclide release pathways, specifically for H-3 and C-14. Only PWR fuel was evaluated in their study. While no significant difference between PWR and BWR fuel behavior was expected, there was a desire to confirm BWR behavior. The specific behavior of cladding splitting was not fully understood at all temperatures of interest, as data and testing of SNF were sparse. This is an area where targeted experimentation and parametric studies with modeling may prove very beneficial in new studies in this area.

Gaps in the understanding of $\mathrm{UO}_{2}$ oxidation are further defined in a report by the Civilian Radioactive Waste Management Service (CRWMS) [4]. This report summarizes much of the research conducted between the Einziger and Strain summaries [1,2] in 1986 and the writing of the Civilian Radioactive Waste Management report in 2000. One of the most significant derivations from Hanson's CRWMS report [4] is the derivation of incubation time to $\mathrm{U}_{3} \mathrm{O}_{8}$ as a function of burnup based on the data in Hanson's earlier work [5]. For dry air, the following model from the CRWMS report [4] is conservative and relatively easy to apply to a variety of fuel handling situations.

$$
t_{i n c}=k_{2.4} e^{\frac{Q_{2.4}}{R T}}+\lambda_{i n c} k_{75} e^{\frac{Q_{75}+\alpha \times B U}{R T}}
$$

where

$$
\begin{array}{ll}
\mathrm{t}_{\text {inc }}= & \text { incubation time in hours } \\
\mathrm{k}_{2.4}= & \text { is the pre-exponential factor for the } \mathrm{UO}_{2} \text { to } \mathrm{UO}_{2.4} \text { transition }(\mathrm{h}) \\
& \text { Nominal Case: } 1.40 \times 10^{-8}, \text { Bounding Case } 2.93 \times 10^{-9} \\
\mathrm{Q}_{2.4}= & \text { in the activation energy }\left(105 \mathrm{~kJ} \mathrm{~mol}^{-1}\right) \\
\mathrm{R}= & \text { the universal gas constant } \\
\mathrm{T}= & \text { the temperature in Kelvin } \\
\mathrm{k}_{75}= & \text { the pre-exponential factor for the } \mathrm{UO}_{2.4} \text { to } \mathrm{U}_{3} \mathrm{O}_{8} \text { transition }(\mathrm{h}) \\
& \text { Nominal Case: } 4.84 \times 10^{-14}, \text { Bounding Case: } 1.48 \times 10^{-14} \\
\lambda_{\text {inc }}= & \text { This is a geometric term related to the outer radius of the fuel } \\
& \text { and the inner radius of the cladding. For the no gap case it is } \\
& 6.30 \times 10^{-3} \text {. } \\
\mathrm{Q}_{75}= & \text { Arrhenius activation energy for } \mathrm{UO}_{2.4} \text { to } \mathrm{U}_{3} \mathrm{O}_{8} 150 \mathrm{~kJ} \text { mol-1 } \\
\alpha= & 1.0 \mathrm{~kJ} \text { mol per } \mathrm{MWd} / \mathrm{kgU} \\
\mathrm{BU}= & \text { local burnup of the sample }\left(\mathrm{MWd} / \mathrm{kgU}^{-1}\right)
\end{array}
$$

The nominal and bounding case curves from these values are shown in Figure 1. Operational scenarios would have fuel exposed to for about 100 hours and accident scenarios could have the fuel exposed to air for 1000 hours. For 100 hours of incubation time, the key temperature to stay below is 
$250^{\circ} \mathrm{C}$ for the bounding case and $280^{\circ} \mathrm{C}$ for the nominal case. At 1000 hours of incubation time, the key temperature to stay below is $200^{\circ} \mathrm{C}$ for the bounding case and $230^{\circ} \mathrm{C}$ for the nominal case.

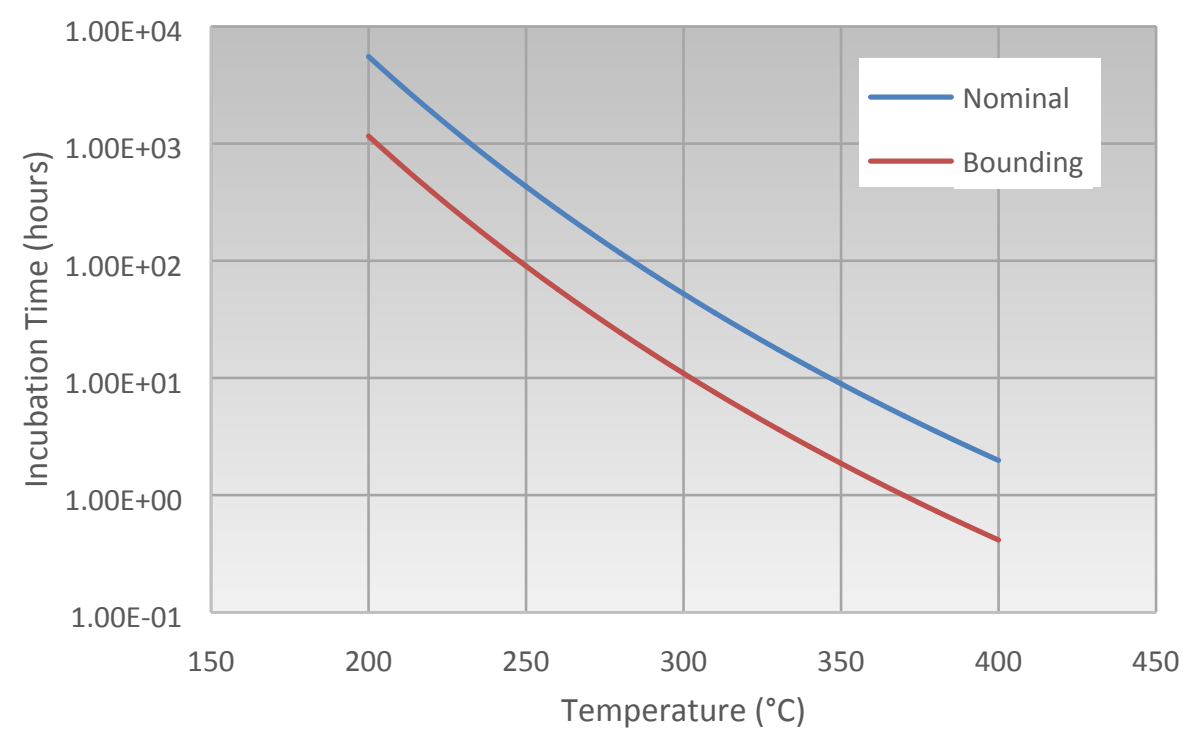

Figure 1. Incubation time to the initiation of a defect due to dry oxidation of the fuel

Grain size at end of life is expected to have some effect on the progression of oxidation in CSNF and some effect on the final respirable fraction released from an accident. This is due to the progression of oxidation along the grain boundaries [3]. Work to specify the effect of grain size on oxidation was also performed [6], but there was not a clear relationship established for typical $\mathrm{UO}_{2}$ grains, and the effect of high burnup structure (HBS) $\mathrm{UO}_{2}[7,8]$ was not established. This research on grain size notes that oxidation data for high burnup $\mathrm{UO}_{2}$ above $45 \mathrm{MWd} / \mathrm{kgU}$ needed to be established. The final conclusion from Hanson [3] was that assuming an as-fabricated grain structure for most fuels was still a conservative assumption for most fuels. Grains tend to grow in $\mathrm{UO}_{2}$ under irradiation, with the exception of HBS formation.

Work on BWR fuel [9] and CANDU fuel [10] is also presented in the CRWMS report [4], but no readily significant change in the behavior of these fuels vs. PWR fuel is reported. Typical BWR discharge burnups are also lower than PWR burnups, making BWR assemblies less likely to be the bounding case for a fuel handling facility. The effect of fission products has also been considered in some research $[11,12]$ and is currently incorporated into incubation time by the burnup term, as indicated in Eq. (1). However, with higher burnup fuel that has experienced varied burnup histories, it may be important to consider rare earth content directly and not just as an empirical burnup factor.

Extensive work on irradiated higher burnup CSNF is summarized in Hanson's 2008 report [3]. One of the major conclusions from this work was that high burnup structure had little impact on the particle size distribution of oxidized fuel. Although in the summary it is acknowledged that there is some conflict in the literature. This is also in contradiction to some more recent observations of HBS behavior under certain accident scenarios [7,13-16]. The behavior of HBS at temperatures used in fuel handling scenarios may be significantly different from its behavior under in-pile conditions. It will be important to resolve this inconsistency in any future proposed work. Unfortunately, the method used to evaluate mass gain in previous work had high uncertainties. Irradiated fuel was oxidized in a test apparatus, and then the mass was measured again after oxidation. It is not clear why mass gain was not monitored continuously. The proposed work will seek to conduct similar measurements in a thermogravimetric analyzer to better capture the kinetics of oxidation.

The effect of water is less well understood than the effects of air, but has also been studied previously [17-19]. When considering water, two distinct scenarios must be considered. In one case, failed fuel may 
be exposed to a water environment either in a fuel handling pool or from a pre-existing defect that causes a pin to become filled with water. In another case, the fuel may be exposed to an environment with a mixture of air and water vapor. Either scenario changes the kinetics of oxidation and introduces hydrogen, which further complicates the progression of $\mathrm{UO}_{2}$ oxidation, or may accelerate cladding failure by hydriding the cladding.

Research has also investigated the particle sized distribution of aerosol powders released from CSNF from oxidation and mechanical agitation [3]. This study was limited to only 4 irradiated fuel samples. Clearly there is need for additional data in this area. The overall study of fuel particle dispersal from various different defects and oxidation scenarios is not yet fully defined in the literature.

\section{GAPS IN THE UNDERSTANDING OF CSNF OXIDATION}

The previous section briefly covers several decades of extensive research into the oxidation of $\mathrm{UO}_{2}$. To the first order, the oxidation of CSNF with preexisting flaws is understood. However, the limitations that arise from working with irradiated fuel and the evolution of light-water reactor (LWR) fuel over the past few decades have still left some gaps in the full understanding of CSNF in an air environment.

contains several variables that may impact CNSF oxidation and the dispersal of particulates

following an accident. The state of knowledge on each variable is summarized, and proposed testing to improve understanding of each effect is defined, with some justification provided.

contains several variables that may impact CNSF oxidation and the dispersal of particulates following an accident. The state of knowledge on each variable is summarized, and proposed testing to improve understanding of each effect is defined, with some justification provided. 
Table 1. Variables That May Impact CNSF Oxidation and the

Dispersal of Particulates Following an Accident

\begin{tabular}{|c|c|c|}
\hline Variable & State of knowledge & Proposed testing \\
\hline \multicolumn{3}{|c|}{ Tests on $\mathrm{UO}_{2}$} \\
\hline $\begin{array}{l}\text { Basic oxidation } \\
\text { kinetics of } \mathrm{UO}_{2}\end{array}$ & $\begin{array}{l}\text { This variable is well known and has } \\
\text { been tested at several temperatures for } \\
\text { standard } \mathrm{UO}_{2} \text { powders }[1-4] \text {. }\end{array}$ & $\begin{array}{l}\text { Some basic testing of } \mathrm{UO}_{2} \text { powder oxidation is } \\
\text { proposed to baseline other measurements proposed in } \\
\text { this test plan. Also, some oxidation tests may be } \\
\text { performed inside an XRD to better characterize the } \\
\text { progression of } \mathrm{UO}_{2} \text { through the different oxidation } \\
\text { states. }\end{array}$ \\
\hline Grain size effect & $\begin{array}{l}\text { No effect due to grain size has been } \\
\text { observed in the literature to date. This } \\
\text { includes some integral work on } \\
\text { irradiated fuel that contained HBS [3]. }\end{array}$ & $\begin{array}{l}\text { No testing is proposed at this time; future capabilities } \\
\text { in synthesis of nano-grain } \mathrm{UO}_{2} \text { may enable } \\
\text { characterization of grain size effects in unirradiated } \\
\mathrm{UO}_{2} \text {. }\end{array}$ \\
\hline $\begin{array}{l}\text { Dissolved fission } \\
\text { products and } \\
\text { plutonium } \\
\text { content (burnup) } \\
\text { effect }\end{array}$ & $\begin{array}{l}\text { A factor accounting for burnup has } \\
\text { been proposed for the working model } \\
\text { derived in the CRWMS report [4], but } \\
\text { the data used to determine this factor } \\
\text { were quite scattered. The oxidation } \\
\text { behavior of } \mathrm{UO}_{2} \text { will be impacted by } \\
\text { the oxygen potential in the fuel, which } \\
\text { is impacted by the fuel's fission product } \\
\text { and Pu content. To a first order, this } \\
\text { content can be captured by a simple } \\
\text { burnup term, but a more mechanistic } \\
\text { model should be developed, especially } \\
\text { to capture the behavior of higher } \\
\text { burnup LWR fuels that have become } \\
\text { the norm in the fleet. }\end{array}$ & $\begin{array}{l}\text { Oxidation kinetics of unirradiated } \mathrm{UO}_{2} \text { doped with } \\
\text { known amounts of dissolved surrogate fission } \\
\text { products and surrogate } \mathrm{Pu} \text {, primarily } \mathrm{Ce} \text {, will be } \\
\text { fabricated to mechanistically understand the oxidation } \\
\text { kinetics of this simulated burnup fuel (SIMFUEL). } \\
\text { The results can be applied more consistently to all } \\
\text { fuel destined for the repository. }\end{array}$ \\
\hline Additive impact & $\begin{array}{l}\text { Vendors have begun to introduce doped } \\
\mathrm{UO}_{2} \text { fuels into light LWRs [20] to } \\
\text { enlarge grain size, which is intended to } \\
\text { slow fission gas release during normal } \\
\text { operating conditions and to limit pellet- } \\
\text { cladding mechanical interaction by } \\
\text { modifying the fuel's mechanical } \\
\text { properties. This fuel has not been } \\
\text { evaluated by prior studies. }\end{array}$ & $\begin{array}{l}\text { The impact of additives such as aluminum oxide, } \\
\text { chromium oxide and gadolinium oxide will be } \\
\text { evaluated by oxidation kinetics studies over the } \\
\text { temperature range applicable to fuel accident } \\
\text { scenarios. This will be very complementary to studies } \\
\text { on dissolved fission products and Pu surrogates. }\end{array}$ \\
\hline $\begin{array}{l}\text { Integral irradiated } \\
\mathrm{UO}_{2} \text { testing }\end{array}$ & $\begin{array}{l}\text { The current data set on high burnup } \\
\mathrm{LWR} \mathrm{UO}_{2} \text { is limited to the few samples } \\
\text { evaluated in the Hanson et al. Fuel-in- } \\
\text { Air FY07 Summary Report [3]. }\end{array}$ & $\begin{array}{l}\text { The scatter in the available data and increasing } \\
\text { discharge burnups from the commercial fleet indicate } \\
\text { that the need remains to further test the oxidation } \\
\text { kinetics of irradiated } \mathrm{UO}_{2} \text {. }\end{array}$ \\
\hline
\end{tabular}




\begin{tabular}{|c|c|c|}
\hline \multicolumn{3}{|c|}{$\begin{array}{l}\text { Table 2. Variables That May Impact CNSF Oxidation and the } \\
\text { Dispersal of Particulates Following an Accident (continued) }\end{array}$} \\
\hline Variable & State of knowledge & Proposed testing \\
\hline \multicolumn{3}{|c|}{ Zirconium testing } \\
\hline \begin{tabular}{l|} 
High-temperature \\
creep and burst \\
behavior of \\
irradiated \\
zircaloy
\end{tabular} & $\begin{array}{l}\text { The thermal creep properties of } \\
\text { irradiated zircaloy are well known up to } \\
400^{\circ} \mathrm{C} \text {, but they are not well known } \\
\text { above that temperature. }\end{array}$ & $\begin{array}{l}\text { If an applicable accident can be identified, then creep } \\
\text { behavior of fresh and pre-hydrided zircaloy will be } \\
\text { investigated above } 400^{\circ} \mathrm{C} \text {. The orientation of zircaloy } \\
\text { hydrides may also be analyzed. This could include } \\
\text { investigating zircaloy burst behavior in the absence of } \\
\text { a through-cladding defect. At some temperatures and } \\
\text { internal pressures, it may be possible to fail zircaloy } \\
\text { with only partial damage to wall thickness. }\end{array}$ \\
\hline $\begin{array}{l}\text { Defect size and } \\
\text { shape effect }\end{array}$ & This variable has not been fully studied. & $\begin{array}{l}\text { Some work with nonradioactive surrogate ceramic } \\
\text { pellets that oxidize in a manner similar to that of } \mathrm{UO}_{2} \\
\text { will be performed. Additional work with } \mathrm{UO}_{2} \text { and } \\
\text { SIMFUEL } \mathrm{UO}_{2} \text { will benchmark the behaviors of } \\
\text { different defect sizes and shapes. }\end{array}$ \\
\hline \multicolumn{3}{|c|}{ Integral system testing } \\
\hline $\begin{array}{l}\text { Cladding } \\
\text { unzipping from } \\
\text { oxidation }\end{array}$ & $\begin{array}{l}\text { Cladding unzipping during fuel } \\
\text { handling has been a known issue since } \\
\text { the early } 1980 \text { s [21]. It is known that } \\
\mathrm{UO}_{2} \text { will strain cladding as it oxidizes } \\
\text { to } \mathrm{U}_{3} \mathrm{O}_{8} \text {, but most work has been } \\
\text { focused on understanding the time to } \\
\mathrm{U}_{3} \mathrm{O}_{8} \text { formation because the unzipping } \\
\text { process is very complex. }\end{array}$ & $\begin{array}{l}\text { Small lengths of refabricated, irradiated LWR fuel } \\
\text { with different defect sizes will be tested in existing } \\
\text { furnaces to allow for the study of the progression of } \\
\text { cladding unzipping. }\end{array}$ \\
\hline $\begin{array}{l}\text { Defect size and } \\
\text { shape effect }\end{array}$ & Not fully studied & $\begin{array}{l}\text { This will be covered by the testing campaign } \\
\text { described in the item above; surrogates will be used to } \\
\text { gain a better understanding of the problem before } \\
\text { irradiated material is used. }\end{array}$ \\
\hline Aerosol behavior & $\begin{array}{l}\text { Aerosol behavior has been studied [3], } \\
\text { but more work should be done to } \\
\text { expand this data set. The distribution of } \\
\text { particles is known, but the composition } \\
\text { of different particle sizes is not known. }\end{array}$ & $\begin{array}{l}\text { Additional aerosol samples will be collected in } \\
\text { parallel with other tests planned on irradiated fuel. } \\
\text { The compositions of the different particle sizes will } \\
\text { be investigated by electron microscopy to determine } \\
\text { if they vary. If particles form from different regions in } \\
\text { the fuel, then certain high-dose consequence fission } \\
\text { products }(\mathrm{Cs}, \mathrm{I}) \text { and actinides (Pu, Am) may reside in } \\
\text { the aerosol particles of a specific side. }\end{array}$ \\
\hline \multicolumn{3}{|c|}{ Water vapor } \\
\hline \begin{tabular}{|l|} 
Effect of water \\
vapor on \\
oxidation kinetics
\end{tabular} & $\begin{array}{l}\text { The effect of water is less well } \\
\text { understood but has been studied } \\
\text { previously [17-19]. It is known that } \\
\text { water influences the sintering kinetics } \\
\text { of } \mathrm{UO}_{2} \text { at much higher temperatures. }\end{array}$ & $\begin{array}{l}\text { An initial experiment to study the oxidation kinetics } \\
\text { of } \mathrm{UO}_{2} \text { at fuel handling accident relevant } \\
\text { temperatures } 300-600^{\circ} \mathrm{C} \text { is proposed for cases in } \\
\text { which air plus significant humidity are used in testing. } \\
\text { If the result differs significantly from the dry air case, } \\
\text { then many of the other experiments proposed will } \\
\text { need to be repeated with water vapor. }\end{array}$ \\
\hline
\end{tabular}




\section{PROPOSED WORK SCOPE}

After considering the gaps discussed in the previous section, a work scope was developed to begin closing the gaps:

1. Compile a complete data set of oxidation kinetics tests on $\mathrm{UO}_{2}$ powders, $\mathrm{UO}_{2}$ powders with known concentrations of dopants, and irradiated materials at temperatures that span dry storage and fuel handling accident conditions. Dopants include simulated fission products, simulated $\mathrm{Pu}$ surrogates, and fuel performance additives used in the most recent LWR fuel.

2. Evaluate the behavior of fresh and irradiated zirconium alloys at elevated temperatures relevant to fuel handling accidents.

3. Execute a novel experimental approach to assess the impact of rapid depressurization following cladding failure at low temperature storage conditions on fuel integrity and particulate release. Perform experiments to facilitate improved understanding of cladding failure propagation (unzipping) as a function of fuel state.

4. Provide first-of-a-kind mechanistic data on the impact of moisture in storage and fuel handling accident oxidation behavior and radioactivity release.

Oxidation kinetics studies on $\mathrm{UO}_{2}$ are proposed to better mechanistically quantify the incubation time behavior of irradiated $\mathrm{UO}_{2}$. Two primary methods are proposed. The kinetics of the $\mathrm{UO}_{2}$ to $\mathrm{U}_{3} \mathrm{O}_{8}$ reaction will be monitored using thermogravimetric analysis (TGA) from approximately $250^{\circ} \mathrm{C}$ up to 500 or $600^{\circ} \mathrm{C}$, depending on input to be obtained from thermal analysis of fuel handling accidents. In addition to the mass change information that can be attained from TGA, crystallographic information can be obtained from in-situ oxidation testing in an x-ray diffractometer (XRD). Both of these techniques will be baselined on fresh $\mathrm{UO}_{2}$ powder and compared to the standard incubation time equation. $\mathrm{UO}_{2}$ with dopants (SIMFUEL) and additives will then be tested in a similar manner. The SIMFUEL measurements will allow for the modification of the incubation time equation to more accurately reflect the final state of the fuel prior to procedurally complex irradiated fuel measurements are taken. Finally, TGA measurements on irradiated $\mathrm{UO}_{2}$ will be performed to confirm the SIMFUEL measurements and to obtain improved data on irradiated fuel oxidation testing.

The severity of a fuel handling accident is exacerbated by the crack behavior of zircaloy alloys that continue to expose fresh $\mathrm{UO}_{2}$ to air at elevated temperatures. The burst and unzipping behavior of irradiated zircaloy is driven by the thermal creep and fracture toughness of irradiated zircaloy, which is not well known above LWR operating temperatures $\left(>\sim 400^{\circ} \mathrm{C}\right)$. These mechanical properties are also impacted by the prior thermal history of the cladding. Particularly, if hydride reorientation has occurred in the cladding, the creep and fracture toughness may cause the zirconium to fail particularly severely.

Thermal creep tests can be performed on fresh and pre-hydrided cladding to simulate high burnup and dry storage conditions. Fracture toughness testing can also be performed on fresh and pre-hydrided cladding. These basic mechanical properties are imperative to mechanistically understand fuel unzipping, and they could simulate the progression of fuel handling accidents beyond the experimental basis.

The first two parts of this test plan will lead to the confirmatory integral testing . Integral tests will begin with nonradioactive surrogate testing. Pellets that approximate the oxidation behavior of $\mathrm{UO}_{2}$, perhaps $\mathrm{CeO}_{2}$ or $\mathrm{ZrO}_{2}$, will be placed in zirconium cladding with preexisting flaws under an oxidizing atmosphere at elevated temperatures. This testing on fresh and hydrided cladding should inform the severity of oxidation accidents prior to testing of $\mathrm{UO}_{2}$-bearing fuel or irradiated fuel. This will also inform the sample lengths necessary for irradiated fuel testing. The confirmatory integral testing will leverage prior Advanced Fuels Campaign work on burst testing in the prototype Severe Accident Test 
Station (SATS), and it may also be conducted in the prototype SATS furnace. Similar tests on unirradiated $\mathrm{UO}_{2}$ and unirradiated doped $\mathrm{UO}_{2}$ should follow in equivalent furnaces that are approved for uranium work. The surrogate and unirradiated $\mathrm{UO}_{2}$ tests will also identify if there is a defect size and shape effect on cladding unzipping. Testing of round hole, longitudinal cracks, and circumferential cracks can all be tested in these configurations before tests are conducting using irradiated fuel testing. These tests will inform irradiated fuel testing in the hot cell SATS. During the testing, particles produced by cladding failure will be collected to determine the distribution of aerosol particles that may be produced during an accident. This distribution ultimately informs the potential dose to workers or the public. This approach to irradiated fuel testing should produce a more mechanistic data set that is well understood and that minimizes expensive hot cell testing.

At temperatures relevant to sintering $\mathrm{UO}_{2}\left(\sim 1600^{\circ} \mathrm{C}\right)$, small additions of water can greatly affect the progression of oxygen diffusion and sintering kinetics. It is less clear how $\mathrm{H}_{2} \mathrm{O}$ in different concentrations will impact fuel handling accidents. All prior parts of this test plan will be performed under dry air conditions. Many of the tests proposed previously will be repeated with controlled $\mathrm{H}_{2} \mathrm{O}$ additions to the atmosphere to capture the impact of humidity on oxidation. If it is shown that humidity does not have a significant impact on oxidation at relevant temperatures, then humidity testing will not progress all the way to full-scale integral irradiated fuel testing.

The proposed schedule is subject to funding levels as follows. In the first year, testing on $\mathrm{UO}_{2}$ and $\mathrm{UO}_{2}$ with additives will be performed using existing equipment. Some development of $\mathrm{UO}_{2}$ with additives will be necessary, but existing sol-gel technology will allow for at least Ce incorporation into prepared $\mathrm{UO}_{2}$ SIMFUEL powders. An XRD for in-situ testing will be identified, and an environmental chamber for oxidation testing in the XRD will be procured. A TGA for irradiated fuel testing will be procured and installed in the Irradiated Fuels Examination Laboratory (IFEL) at Oak Ridge National Laboratory (ORNL) for future irradiated fuel TGA testing in the next year. Further review of existing zirconium alloy creep and fracture toughness data will be performed. Efforts to fill gaps in the data up to hydriding levels expected in high burnup LWR fuels will be initiated in the first year of the project. Integral testing in prototype SATS with surrogate pellets will also be initiated in the first year. Integral $\mathrm{UO}_{2}$ and irradiated fuel testing will be delayed to the second year and out years. Only limited $\mathrm{H}_{2} \mathrm{O}$ work if any will be performed in the first year of the project subject to initial dry air testing.

\section{SUMMARY}

Fully understanding the progression of irradiated fuel handling accidents requires additional data. Gaps exist primarily (1) at the highest burnup levels, (2) in new fuel forms that incorporated in-pile fuel performance-enhancing additives, and (3) concerning the impact of water on the progression of oxidation. This test plan proposes to close these gaps through a tiered approach that maximizes the mechanistic understanding of this problem while minimizing the necessary irradiated fuel testing. These tests will include the study of oxidation kinetics in $\mathrm{UO}_{2}$, SIMFUEL $\mathrm{UO}_{2}$, and irradiated LWR fuel, as well as the mechanical properties of zirconium alloys. This new understanding will be leveraged to support integral testing, and where applicable, it will be applied to tests regarding the impact of water vapor on oxidation. 


\section{REFERENCES}

[1] R.E. Einziger, R. V Strain, Oxidation of Spent Fuel at Between 250 and 400 C, (1986) EPRI-NP4524, Electric Power Research Institute.

[2] R.E. Einziger, R. V Strain, Behavior of Breached Pressurized Water Reactor Spent-Fuel Rods in an Air Atmosphere between 250 and $360^{\circ} \mathrm{C}$, Nucl. Technol. 75 (1986) 82-95. doi:10.13182/NT86A15979.

[3] B.D. Hanson, R.C. Daniel, A.M. Casella, R.S. Wittman, W. Wu, P.J. MacFarlan, R.W. Shimskey, Fuel-in-Air FY07 Summary Report, United States, 2008. doi:10.2172/1214085.

[4] B.D. Hanson, Civilian Radioactive Waste Management Service - Management and Operations, Clad Degradation - Dry Unzipping, (2000) ANL-EBS-MD-000013.

[5] B.D. Hanson, The Burnup Dependence of Light Water Reactor Spent Fuel Oxidation, United States, 1998. doi:10.2172/291169.

[6] B.D. Hanson, E.J. Kansa, R.B. Stoot, Grain and Burnup Dependence of Spent Fuel Oxidation: Geological Repository Impact, 1998. PNNL-11929, Pacific Northwest National Laboratory, doi:10.2172/291169.

[7] V. V Rondinella, T. Wiss, The High Burn-Up Structure in Nuclear Fuel, Mater. Today. 13 (2010) 24-32. doi:https://doi.org/10.1016/S1369-7021(10)70221-2.

[8] C.T. Walker, T. Kameyama, S. Kitajima, M. Kinoshita, Concerning the Microstructure Changes that Occur at the Surface of $\mathrm{UO}_{2}$ Pellets on Irradiation to High Burnup, J. Nucl. Mater. 188 (1992) 73-79. doi:10.1016/0022-3115(92)90456-U.

[9] R. Kohli, D. Stahl, V. Pasupathi, A.B. Johnson, E.R. Gilbert, The Behavior of Breached Boiling Water Reactor Fuel Rods on Long-Term Exposure to Air and Argon at 598 K, Nucl. Technol. 69 (1985) 186-197. doi:10.13182/NT85-A33630.

[10] R.J. McEachern, P. Taylor, A Review of the Oxidation of Uranium Dioxide at Temperatures below $400^{\circ} \mathrm{C}, \mathrm{J}$. Nucl. Mater. 254 (1998) 87-121. doi:10.1016/S0022-3115(97)00343-7.

[11] R.J. McEachern, J.W. Choi, M. Kolár, W. Long, P. Taylor, D.D. Wood, Determination of the Activation Energy for the Formation of $\mathrm{U}_{3} \mathrm{O}_{8}$ on $\mathrm{UO}_{2}$, J. Nucl. Mater. 249 (1997) 58-69. doi:10.1016/S0022-3115(97)00189-X.

[12] R.J. McEachern, D.C. Doern, D.D. Wood, The Effect of Rare-Earth Fission Products on the Rate of $\mathrm{U}_{3} \mathrm{O}_{8}$ Formation on $\mathrm{UO}_{2}$, J. Nucl. Mater. 252 (1998) 145-149. doi:10.1016/S00223115(97)00286-9.

[13] J. Rest, M.W.D. Cooper, J. Spino, J.A. Turnbull, P. Van Uffelen, C.T. Walker, Fission Gas Release from $\mathrm{UO}_{2}$ Nuclear Fuel: A Review, J. Nucl. Mater. 513 (2019) 310-345. doi:10.1016/j.jnucmat.2018.08.019.

[14] C. Baker, The Migration of Intragranular Fission Gas Bubbles in Irradiated Uranium Dioxide, $J$. Nucl. Mater. 71 (1977) 117-123. doi:10.1016/0022-3115(77)90195-7.

[15] M. Tonks, D. Andersson, R. Devanathan, R. Dubourg, A. El-Azab, M. Freyss, F. Iglesias, K. Kulacsy, G. Pastore, S.R. Phillpot, M. Welland, Unit Mechanisms of Fission Gas Release: Current Understanding and Future Needs, J. Nucl. Mater. 504 (2018) 300-317. doi:10.1016/J.JNUCMAT.2018.03.016.

[16] J.A. Turnbull, S.K. Yagnik, M. Hirai, D.M. Staicu, C.T. Walker, An Assessment of the Fuel Pulverization Threshold during LOCA-Type Temperature Transients, Nucl. Sci. Eng. 179 (2015) 477-485. doi:10.13182/NSE14-20.

[17] P. Taylor, D.D. Wood, A.M. Duclos, D.G. Owen, Formation of Uranium Trioxide Hydrates on $\mathrm{UO}_{2}$ Fuel in Air-Steam Mixtures near $200^{\circ} \mathrm{C}, J$. Nucl. Mater. 168 (1989) 70-75.

doi:10.1016/0022-3115(89)90566-7. 
[18] P. Taylor, R.J. Lemire, D.D. Wood, The Influence of Moisture on Air Oxidation of $\mathrm{UO}_{2}$ : Calculations and Observations, Nucl. Technol. 104 (1993) 164-170. doi:10.13182/NT93-A34880.

[19] S.B. Donald, M.L. Davisson, Z. Dai, S.K. Roberts, A.J. Nelson, Relative Impact of $\mathrm{H}_{2} \mathrm{O}$ and $\mathrm{O}_{2}$ in the Oxidation of $\mathrm{UO}_{2}$ Powders from 50 to $300{ }^{\circ} \mathrm{C}$, J. Nucl. Mater. 496 (2017) 353-361. doi:10.1016/J.JNUCMAT.2017.10.014.

[20] J. Arborelius, K. Backman, L. Hallstadius, M. Limbäck, J. Nilsson, B. Rebensdorff, G. Zhou, K. Kitano, R. Löfström, G. Rönnberg, Advanced Doped $\mathrm{UO}_{2}$ Pellets in LWR Applications, J. Nucl. Sci. Technol. 43 (2006) 967-976. doi:10.1080/18811248.2006.9711184.

[21] B.W. Carlsen, E. Woolstenhulme, R. McCormack, Damaged Spent Nuclear Fuel at U.S. DOE Facilities Experience and Lessons Learned, United States, 2005. INL/EXT--05-00760, Idaho National Laboratory, doi:10.2172/911592.

O 